Journal of the Geological Society

Middle Pleistocene glacier behaviour in the Mediterranean: sedimentological evidence from the Pindus Mountains, Greece

P.D. Hughes, P.L. Gibbard and J.C. Woodward

Journal of the Geological Society 2006; v. 163; p. 857-867

doi:10.1144/0016-76492005-131

Email alerting service

Permission request

Subscribe click here to receive free email alerts when new articles cite this article

click here to seek permission to re-use all or part of this article

click here to subscribe to Journal of the Geological Society or the Lyell Collection

Notes

Downloaded by

University of Manchester on 7 April 2008

๑) 2006 Geological Society of London

Lyell

Collection 


\title{
Middle Pleistocene glacier behaviour in the Mediterranean: sedimentological evidence from the Pindus Mountains, Greece
}

\author{
P. D. HUGHES ${ }^{1}$, P. L. GIBBARD ${ }^{2}$ \& J. C. WOODWARD ${ }^{1}$ \\ ${ }^{1}$ Geography, School of Environment and Development, The University of Manchester, Oxford Road, \\ ManchesterM139PL,UK (e-mail: philip.hughes@manchester.ac.uk) \\ ${ }^{2}$ Cambridge Quaternary, Department of Geography, University of Cambridge, Downing Place, Cambridge CB2 3EN, UK
}

\begin{abstract}
Detailed sedimentological analyses of diamicton sequences in two areas of the Pindus Mountains, Greece, indicate multiple episodes of glacier advance and retreat during cold stages of the Middle-Pleistocene. These glacial sequences represent some of the most southerly in Europe and are important archives of regional and global climate change. The Pindus glaciers were relatively small by world standards and would have been highly responsive to changes in air temperature and precipitation. On Mount Tymphi, at least three phases of glacier advance are recorded within deposits assigned to the Skamnellian Stage (MIS 12). Further north on Mount Smolikas, a thick multiple diamicton sequence records evidence for multiple glacier advances during both the Skamnellian Stage and the Vlasian Stage (MIS 6). These records highlight the dynamic nature of glacier behaviour in the Mediterranean mountains during the Middle Pleistocene and provide new evidence for unstable cold stage climates.
\end{abstract}

The mountains of the Mediterranean were extensively glaciated during cold stages of the Pleistocene (Hughes et al. 2006a). These former glaciers were the most southerly in Europe and their sedimentary records provide an important archive of regional and global climate change. The Mediterranean glaciers were relatively small by world standards and would have been highly responsive to changes in air temperatures and precipitation. This paper presents an analysis of glacial deposits in Greece and investigates, for the first time in the Mediterranean region, the evidence for dynamic glacier-sediment interaction during the cold stages of the Middle Pleistocene. Glacial deposits of Middle Pleistocene age have been recognized at several sites in the Mediterranean including Mount Olympus, Greece (Smith et al. 1997), the Serra de Queira and Serra de Gêrez, in NW Spain and northern Portugal (Fernadez Mosquera et al. 2000), the Italian Apennines (Federici 1980; Kotarba 2001) and the Pyrenees (Calvet 2004). Most studies of the Mediterranean mountains have relied on morphological criteria to subdivide glacial successions, and systematic investigations of the glacial sedimentology are rare. Sedimentological analyses offer the potential to provide much greater insight into former glacier-sediment dynamics, as has been demonstrated in recent glacial environments in high latitudes (e.g. Glasser \& Hambrey 2001). Such studies constitute an important new record of environmental change in the Mediterranean. Where the Pleistocene glacial sediment record in the Mediterranean mountains is well preserved, it can enhance our understanding of the nature of cold stage climates. This evidence can be usefully compared with high-resolution environment records for this region, such as vegetation records from long lacustrine cores (e.g. Tzedakis et al. 2003).

\section{Study area}

The sedimentology of Middle Pleistocene glacial deposits was examined on Mount Tymphi (2497 m above sea level (a.s.1.)) and Mount Smolikas (2637 m a.s.1.), the sixth and second highest peaks in Greece, respectively (Fig. 1). Mount Tymphi is formed of Palaeocene-Eocene limestone whereas Mount Smolikas is formed of ophiolitic rocks of Jurassic age and, in both areas, flysch of Late Eocene to Miocene age is also widespread on the lower slopes. Pleistocene glacial deposits and landforms are widely preserved. (IGME 1970, 1987; Palmentola et al. 1990; Boenzi et al. 1992; Woodward et al. 2004). On Mount Tymphi, glacial and karstic processes have combined to produce a classic glacio-karst landscape covering an area of c. $67 \mathrm{~km}^{2}$. Here, a wide range of glacial geomorphological features and deposits are particularly well preserved. On Mount Smolikas, glacial geomorphological features are less well preserved and the glacial sequence in some cirque-valley systems is typically more fragmentary than on Mount Tymphi. Nevertheless, in some valleys the completeness of the glacial sequence equals that on Mount Tymphi, and in the Vadulakkos valley (Fig. 1b) glacial sediment accumulations reach thicknesses exceeding $30 \mathrm{~m}$ in places.

Woodward et al. (2004) and Hughes et al. (2006b) employed uranium (U-) series dating of secondary carbonate cements within glacial deposits to establish a geochronological framework for the glacial sequence on Mount Tymphi. The glacial record was then integrated with the long pollen sequence at nearby Ioannina (Fig. 1) to develop a chronostratigraphy for cold stages in Greece (Fig. 2). The oldest recorded glacial unit is ascribed to the Skamnellian Stage, and correlated with the Elsterian Stage of northern Europe and marine isotope stage (MIS) 12 (Hughes et al. 2005, 2006b). Glacial deposits at higher elevations characterized by well-preserved mid-valley moraines are ascribed to the Vlasian Stage, and correlated with part of the Saalian stage of northern Europe and MIS 6. The youngest glacial and periglacial deposits on Mount Tymphi (2497 m a.s.1.) formed in the highest cirques above c. $1800 \mathrm{~m}$ a.s.l. (Hughes et al. 2003). These deposits formed during the last cold stage in Greece, named the Tymphian Stage, which corresponds to the last glacial cycle recorded in the marine isotope record incorporating MIS 5d-2 and terrestrial chronostratigraphical units such as the Würmian 

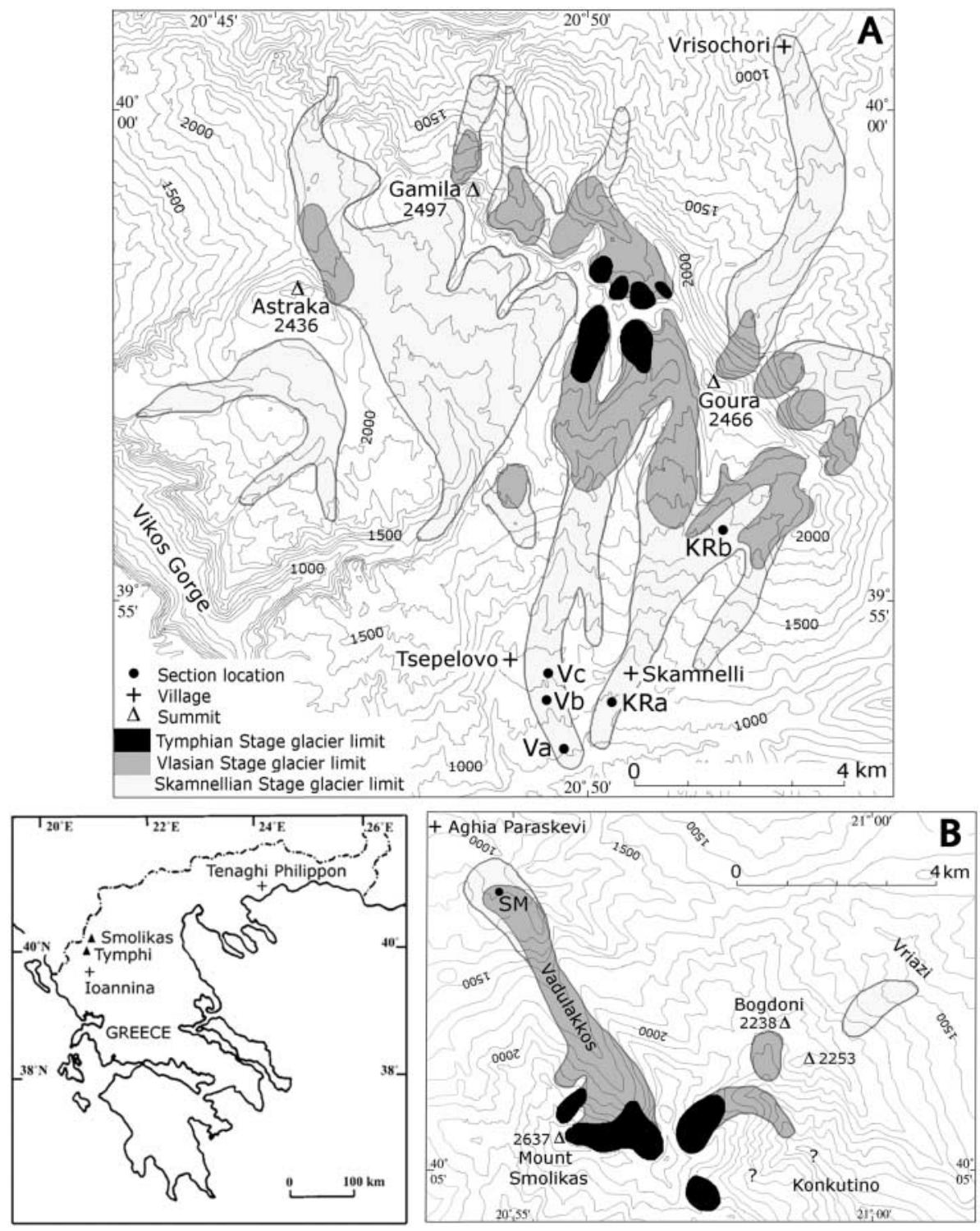

Fig. 1. Location maps showing section locations and the spatial subdivision of glacial limits during the glacial stages on Mount Tymphi (a) and Mount Smolikas (b). Contours are at $100 \mathrm{~m}$ intervals.

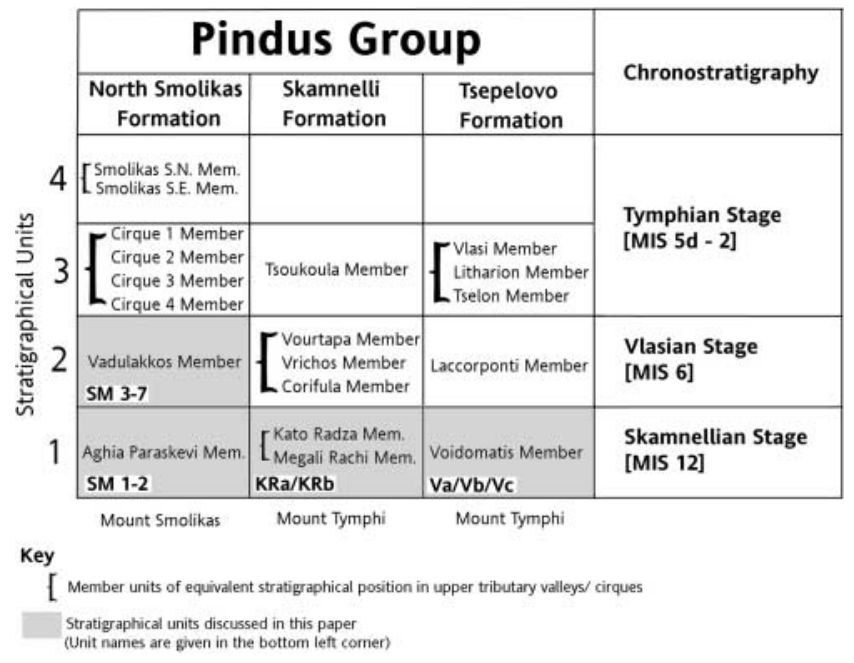

Fig. 2. Stratigraphical summary of the cirque-valley systems discussed in this paper. and Weichselian Stages of the Alps and northern Europe (Hughes et al. 2005, 2006b). The Tymphian Stage deposits are well preserved but are rarely exposed in section and lack the thickness and complexity of sediments of Middle Pleistocene age. On Mount Smolikas, the glacial sequence is similar to that on neighbouring Mount Tymphi but with an additional suite of moraines in cirques above $2200 \mathrm{~m}$ a.s.l., above the highest cirque floors of the latter mountain. Hughes et al. (2006c) have argued that these moraines were formed by glacier readvance during the Late-glacial Substage, although these deposits have not yet been dated.

\section{Methods}

The distribution of glacial sediments and landforms was mapped in the field onto 1:25000 base maps and checked against aerial photographs. Sediment exposures were subdivided on the basis of lithology in conjunction with geomorphological criteria to provide an integrated morpho-lithostratigraphy using established formal lithostratigraphical hierarchial terminology (Hughes et al. 2005). For example, an individual sediment unit exposed in a section through a moraine usually represented 
a bed, the overall sediment-landform assemblage represented a member, and the entire collection of glacial (and periglacial) units in a cirquevalley system, a formation. The collection of formations through this part of the Pindus Mountains then represented the group (Hughes et al. 2005).

Sediment analysis was undertaken at section exposures in road cuttings, aggregate quarries and in natural stream-cut sections. All section locations are shown in Figure 1. Sections were photographed utilizing a visible scale reference and also sketched in the field to determine lateral sedimentological variability. They were then vertically logged using established symbols (e.g. Evans \& Benn 2004, fig. 2.16). Lateral and vertical variations were also sketched for some sections. Clast fabric, roundness and surface features such as striae were determined from a random sample of 50 clasts using standard procedures (e.g. Jones et al. 1999; Evans \& Benn 2004). Where present, samples of matrix were dried at $100{ }^{\circ} \mathrm{C}$ in the laboratory and sieved through a $2 \mathrm{~mm}$ mesh. The fine fraction $(<2 \mathrm{~mm})$ particle size was then analysed using a Malvern Laser Mastersizer. Lithological descriptions followed the terminology outlined by Moncrieff (1989) and subsequently modified for glacial sediments by Hambrey (1994). Lithofacies were given abbreviations designed to differentiate between lithofacies based on the roundness and surface characteristics of clasts in addition to textural classification and sedimentary structures (Fig. 3).

\section{Field sections}

Sedimentological data are presented for three glaciated valleys in the northern Pindus Mountains. The first two are situated near the villages of Tsepelovo and Skamnelli on the southern slopes of Mount Tymphi (Fig. 1a), and the third is situated in the lower Vadulakkos valley near the village of Aghia Paraskevi on the northern slopes of Mount Smolikas (Fig. 1b). Sedimentological descriptions of these stratigraphical units are presented below.

\section{Mount Tymphi: Tsepelovo Formation}

The village of Tsepelovo is situated on the southern slopes of Mount Tymphi and provides the name for a series of sediment and landform units constituting the Tsepelovo Formation. Three sediment sections coded $\mathrm{Va}, \mathrm{Vb}$ and $\mathrm{Vc}$ are described below from the Voidomatis Member, the lowest stratigraphical unit of the Tsepelovo Formation (Fig. 2). The locations of these sections are given in Figure 1.

Section Va. Boulder-covered ground, enclosed on either side by ridges, extends down to the modern channel of the Voidomatis River at an altitude of $c .850 \mathrm{~m}$ a.s.l. and this has been interpreted as moraines (Lewin et al. 1991; Woodward et al. 1995). In this area, the ridges are subdued in form and sections are provided by natural exposures on the channel margins and along a track leading from Tsepelovo village to the river. A sedimentary $\log$ of a sequence exposed at the banks by the Voidomatis River $\left(39^{\circ} 53^{\prime} 30^{\prime \prime} \mathrm{N}, 20^{\circ} 50^{\prime} 01^{\prime \prime} \mathrm{E}, 860 \mathrm{~m}\right.$ a.s.1.) (Fig. 1a) is given in Figure 3.

Section $\mathrm{Vb}$. An excellent exposure in diamicton (c. $3 \mathrm{~m}$ thick) exists on the Tsepelovo to Skamnelli road $\left(39^{\circ} 54^{\prime} 07^{\prime \prime} \mathrm{N}\right.$, $20^{\circ} 49^{\prime} 40^{\prime \prime} \mathrm{E}, 1060 \mathrm{~m}$ a.s.1.) and has been named section $\mathrm{Vb}$ (Fig. 1a). A photograph of this section and a description of the sediments is shown in Figure 4.

Section $V c$. Three well-defined boulder-covered ridges are evident c. 500-1000 $\mathrm{m}$ due east of Tsepelovo village (Fig. 1a). The morphology of the ridge crests is clear, and the two outermost ridges extend southwards towards the Voidomatis River, where their morphology is less well defined. These ridges are dissected by the main Tsepelovo-Skamnelli road, revealing excellent diamicton sections (Woodward et al. 1992, fig. 6). The sedimentology of a quarried section just outside Tsepelovo $\left(39^{\circ} 54^{\prime} 20^{\prime \prime} \mathrm{N}\right.$, $20^{\circ} 49^{\prime} 40^{\prime \prime} \mathrm{E}, 1100 \mathrm{~m}$ a.s.1.) is illustrated and described in Figure 5.

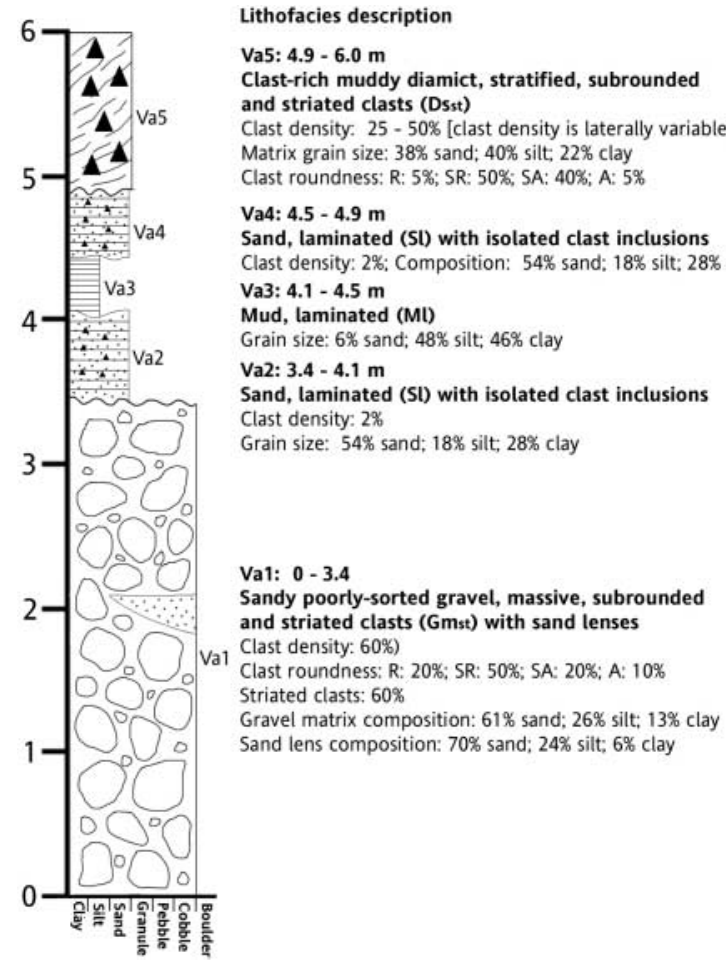

Lithofacies codes

Lithology
$D=$ diamict
$G=$ Gravel
$S=$ Sand
$M=$ Mud
Suffixes
$\mathrm{m}=$ massive
$\mathrm{S}=$ stratified
$\mathrm{b}=$ bedded
$\mathrm{I}=$ laminated
st $=$ subrounded and striated clasts dominant
ang = angular/ subangular clasts dominant

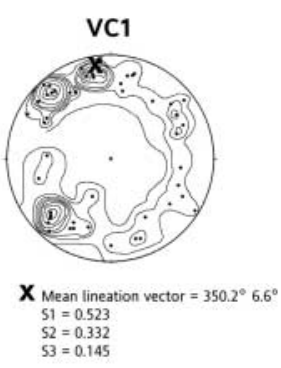

Fig. 3. Lithological $\log$ of the sediments at section $\mathrm{Va}$, in the Voidomatis Member of the Tsepelovo Formation ( $39^{\circ} 53^{\prime} 30^{\prime \prime} \mathrm{N}$, $20^{\circ} 50^{\prime} 01^{\prime \prime} \mathrm{E}, 860 \mathrm{~m}$ a.s.1.). In diamict units, the matrix particle size determined the width of the unit depicted on the log. The contoured clast fabric plot is a equal-area spherical Gaussian stereographic projection of clast orientation produced using Stereonet by Rockware Earth Science Software. The contours are intervals of $1 \%$ per $1 \%$ area. The mean lineation vector displays two values; the first represents direction of dip and the second represents the dip angle. The $S_{1}, S_{2}$ and $S_{3}$ values represent the eigenvalues. 


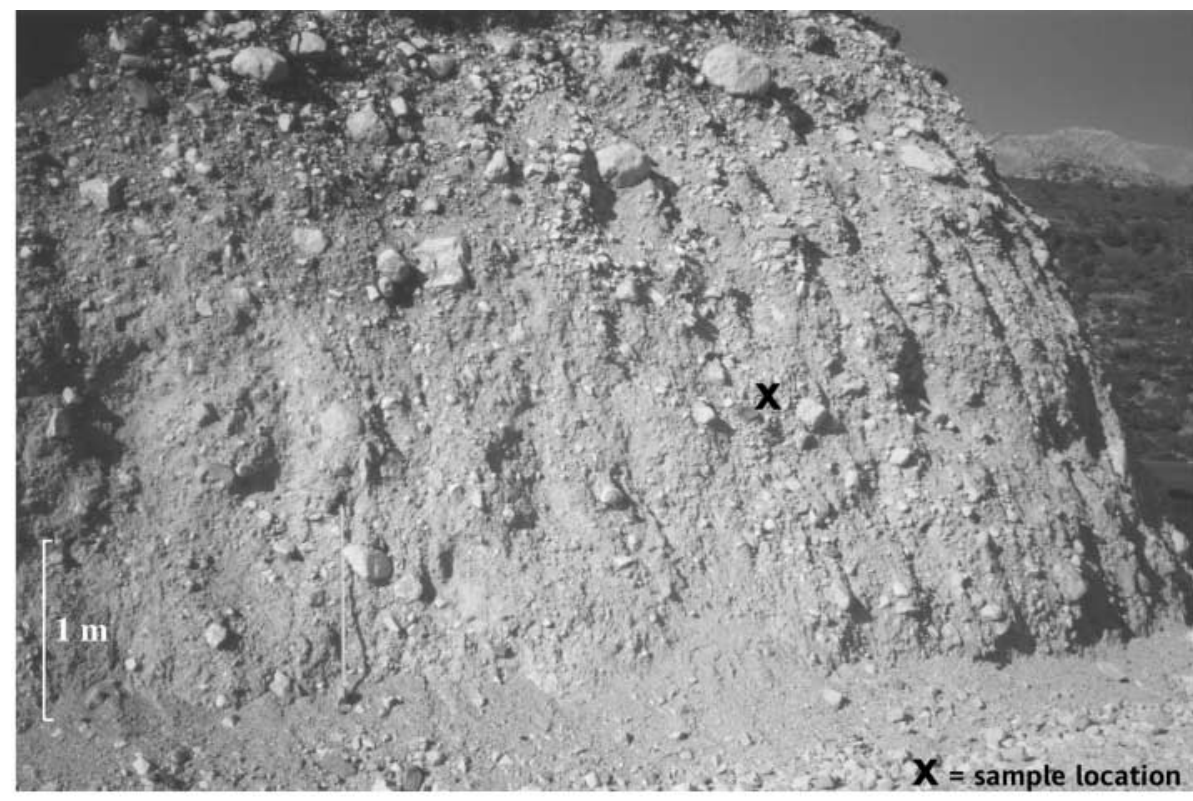

Lithofacies description

Vb: 0 - $4.2 \mathrm{~m}$

Clast-poor muddy diamict, massive, subrounded/ striated clasts (Dmst)

Clast density: $10 \%$.

Mean diameter of 10 largest clasts:

Striated clasts: $46 \%$

Clast roundness: WR: $5 \%$; R: $20 \%$; SR: $25 \%$; SA: $20 \%$;

A: $23 \%$; VA: $7 \%$

Matrix composition: $22 \%$ sand; $28 \%$ silt; $50 \%$ clay

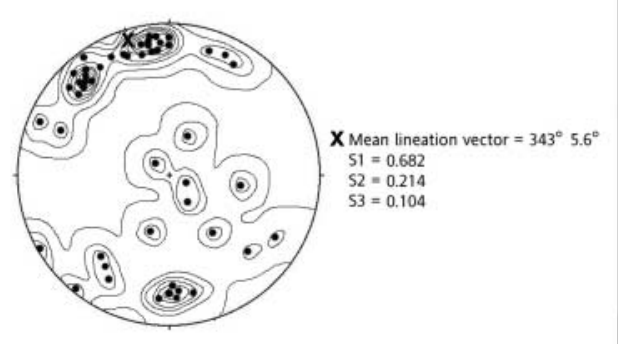

Fig. 4. Photograph and sediment description of section $\mathrm{Vb}$ in the Voidomatis Member of the Tsepelovo Formation at $c$. $39^{\circ} 54^{\prime} 07^{\prime \prime} \mathrm{N}, 20^{\circ} 49^{\prime} 40^{\prime \prime} \mathrm{E}, 1060 \mathrm{~m}$ a.s.l.

\section{Mount Tymphi: Skamnelli Formation}

The Skamnelli Formation comprises a series of sedimentary units in a cirque-valley system (which includes the village of Skamnelli) in a separate valley $5 \mathrm{~km}$ to the east of Tsepelovo on the southern slopes of Mount Tymphi. Sections KRa and KRb are located c. 1.5 and $5 \mathrm{~km}$ up-valley of the limit of glaciation identified by Hughes et al. (2006b) and represent part of the same morpho-lithostratigraphical unit, the Kato Radza Member, the lowest unit of the Skamnelli Formation (Fig. 2). The two sections are described below and the sedimentology is presented in Figures 6 and 7.

Section KRa. This section is situated at $39^{\circ} 54^{\prime} 05^{\prime \prime} \mathrm{N}, 20^{\circ} 50^{\prime} 36^{\prime \prime} \mathrm{E}$, $980 \mathrm{~m}$ a.s.1. (Fig. 1a). It is exposed by a natural stream cutting within a forested area $c .1 .5 \mathrm{~km} \mathrm{SW}$ of Skamnelli village. A section $\log$ is provided in Figure 6.

Section $K R b$. This section is a $4 \mathrm{~m}$ thick exposure situated on a trackside cutting at $39^{\circ} 55^{\prime} 58^{\prime \prime} \mathrm{N}, 20^{\circ} 52^{\prime} 09^{\prime \prime} \mathrm{E}, 1773 \mathrm{~m}$ a.s.1. (Fig. 1a). These sediments are situated outside Vlasian Stage deposits (Fig. 1b) and appear to be contiguous with deposits further down-valley, and therefore represent part of the Kato Radza Member (Fig. 2). The sediments are described alongside a photograph in Figure 7.

\section{Mount Smolikas: North Smolikas Formation}

Boenzi et al. (1992) and Hughes et al. (2006c) have identified moraine ridges in the Vadulakkos valley on the northern slopes of Mount Smolikas and delimited the extent of a large former glacier reaching down to $c$. $1000 \mathrm{~m}$ a.s.l. near to the village of Aghia Paraskevi (Fig. 1b). The deposits of the Vadulakkos valley and its tributary cirques were termed the North Smolikas Formation and arranged into a series of member units by Hughes et al. (2006c) (Fig. 2). A vertical section through more than $30 \mathrm{~m}$ of unconsolidated deposits is exposed at c. $40^{\circ} 08^{\prime} 06^{\prime \prime} \mathrm{N}$, $20^{\circ} 54^{\prime} 50^{\prime \prime} \mathrm{E}, 1080 \mathrm{~m}$ a.s.l. on the southern side of the Aghia Paraskevi to Fouka road (Figs $1 \mathrm{~b}$ and 8).

\section{Facies analysis}

In total, six lithofacies can be identified and these are described in Figures 3-8 and outlined below alongside designated lithofacies abbreviations and interpretations. In all facies, the Mount Tymphi deposits are dominated by limestone-derived sediments with a minor flysch component, whereas the Mount Smolikas sediments are dominated by ophiolite-derived sediments with a minor limestone component.

\section{Diamict, massive with subrounded and striated clasts: $D m_{s t}$}

This lithofacies is interpreted as subglacial till and multiple stacked units are present in the Tsepelovo and Smolikas Formations. This facies varies between clast-rich and clast-poor lithologies with sandy to muddy matrices. However, all contain a dominance of subrounded and striated clasts. Furthermore, where measured, clast fabric is strong and clast mean lineation vectors 


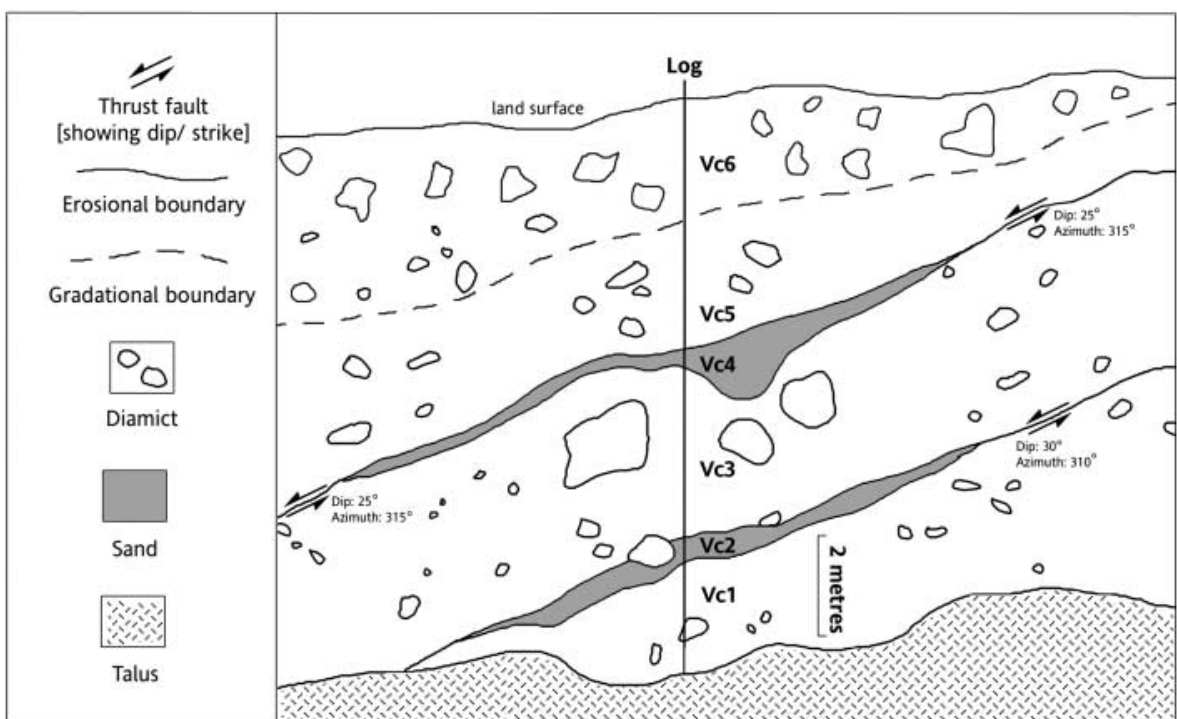

Lithofacies description

Vc6: $7.6-9.0 \mathrm{~m}$

Clast-rich sandy diamict, massive, angular clasts (Dmang)

Clast density: $45 \%$

Clast roundness: SR: 32\%: SA: 38\%: A: 28\%: VA: $2 \%$

Matrix composition: $56 \%$ sand; $32 \%$ silt; $12 \%$ clay

Vc5: 5.6 - $7.6 \mathrm{~m}$

Clast-poor sandy diamict, massive, subrounded/ striated clasts (Dmst)

Clast density: $5 \%$

Clast roundness: WR: $4 \%$; R: 22\%; SR: 48\%; SA: 22\%; A: 4\%

Matrix composition: $47 \%$ sand; $28 \%$ silt; $25 \%$ clay

Vc4: 5.2 - $5.6 \mathrm{~m}$

Sand, massive (Sm)

Composition: 54\% sand; 33\% silt: $13 \%$ clay

Vc3: 2.4 - $5.2 \mathrm{~m}$

Clast-rich sandy diamict, massive, subrounded/ striated clasts (Dmst)

Clast density: $25 \%$

Clast roundness: R: 12\%; SR: 48\%; SA: 26\%: A: $14 \%$

Matrix composition: $42 \%$ sand; $30 \%$ silt; $28 \%$ clay

Vc2: 2.0 - $2.4 \mathrm{~m}$

Sand, massive (Sm)

Composition: $51 \%$ sand; $33 \%$ silt; $16 \%$ clay

Vc1: 0 - $2.0 \mathrm{~m}$

Clast-poor sandy diamict, massive, subrounded and striated clasts (Dmst)

Clast density: $5 \%$

Clast roundness: WR: 6\%; R: 12\%; SR: 48\%; SA: 24\%; A: 8\%; SA: 2

Matrix composition: $47 \%$ sand; $28 \%$ sitt; $25 \%$ clay

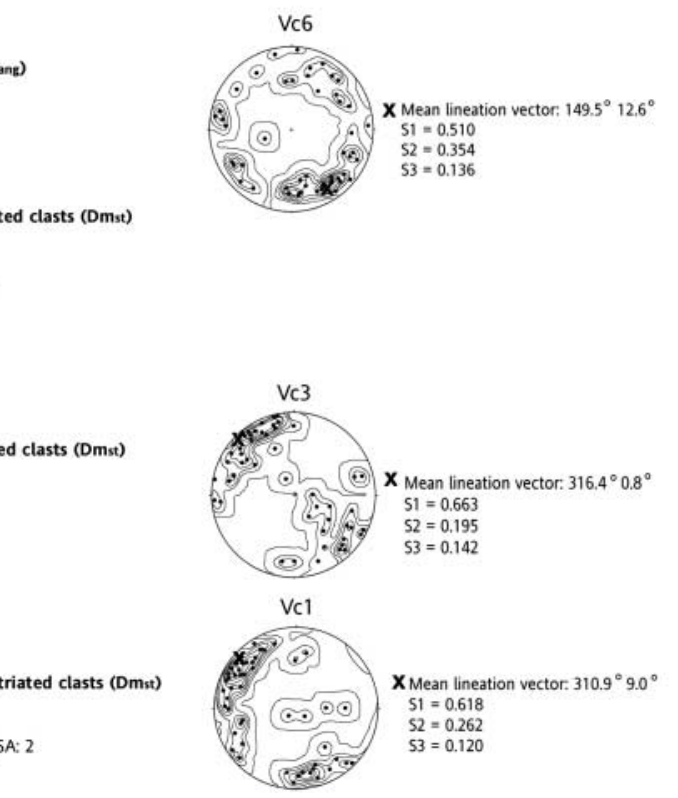

Fig. 5. Sketch and sediment description of section $\mathrm{Vc}$ on the road from Skamnelli to Tsepelovo (39 $54^{\prime} 20^{\prime \prime} \mathrm{N}, 20^{\circ} 49^{\prime} 40^{\prime \prime} \mathrm{E}$, $1100 \mathrm{~m}$ a.s.1.). reflect former ice movement from up-valley areas. Most of the diamicts in this facies have a sandy matrix, with the exception of unit $\mathrm{Vb}$ in the Tsepelovo Formation (Fig. 4), which is a muddy diamict with a clay fraction of $50 \%$. However, on Mount Tymphi all of the deposits in this facies contain at least a $20 \%$ clay fraction and the high percentage of clay fines indicates clast crushing during subglacial transport (Boulton et al. 1974). This facies on Mount Tymphi contains a consistently greater clay-silt fraction compared with similar units on Mount Smolikas and this can be attributed to lithological controls on the production of fines in the subglacial zone and may indicate that the limestones of Tymphi are more susceptible to clast crushing than the ophiolites of Smolikas.

This facies includes sedimentological attributes characteristic of both lodgement and deformation tills. In section $\mathrm{Vb}$ of the Tsepelovo Formation (Fig. 4), the strong clast fabric, presence of striated and subrounded clasts and the clay-rich matrix are characteristic of lodgement till. However, in this diamict unit clast size coarsens upwards and this may be a result of winnowing of fines near the moraine surface. In section Vc of the Tsepelovo Formation and in section SM of the Smolikas Formation on neighbouring Mount Smolikas, diamict units are tilted along thrust faults whereby the upper subglacial till $\left(\mathrm{Dm}_{\mathrm{st}}\right)$ is stacked on an erosional plane dipping up-valley (Figs 5 and 8). These diamicts have strong clast fabrics with low isotropy and moderate to high elongation $\left(\mathrm{S}_{1}>0.6 ; \mathrm{S}_{3} / \mathrm{S}_{1}<0.25 ; 1-\left(\mathrm{S}_{2} / \mathrm{S}_{1}\right)=\right.$ $0.5-0.7)$ parallel to the direction of shear, a property characteristic of sediments that have undergone brittle rather than ductile deformation (see Hart 1994; Benn 1995). Overall, however, cumulative strains must have been low, as sediments are not totally homogenized but are stacked and separated by thrust faults (see Benn \& Evans 1998, pp. 390-394).

\section{Diamict, stratified with subrounded and striated clasts: $D s_{s t}$}

This lithofacies occurs in the Tsepelovo Formation in section Va (Fig. 3) and is interpreted as reworked subglacial till. The fact that 


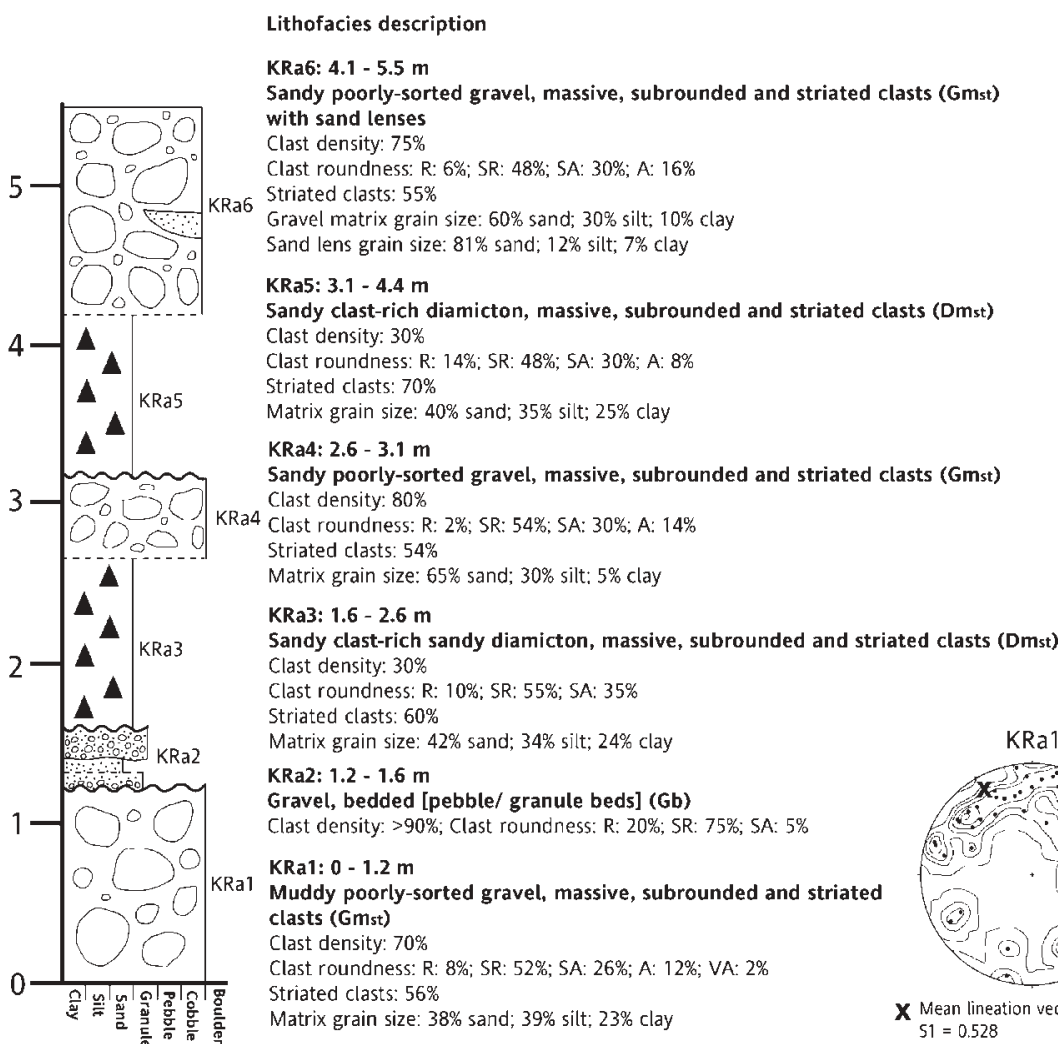

Fig. 6. Lithological log of the sediments at section KRa, in the Kato Radza Member of the Skamnelli Formation $\left(39^{\circ} 54^{\prime} 05^{\prime \prime} \mathrm{N}\right.$, $20^{\circ} 50^{\prime} 36^{\prime \prime} \mathrm{E}, 980 \mathrm{~m}$ a.s.1.). this facies contains a dominance of striated and subrounded clasts supports a subglacial origin. It is similar to Type III flow deposits identified near the Matanuska glacier in Alaska by Lawson (1979) and may represent the subaerial reworking of subglacial tills upon glacier retreat. The weak stratification and the lateral variability in clast density are suggestive of pulsed sediment flow (see Benn \& Evans 1998, p. 409). It is likely that this sediment flow was into a ponded basin, because in section Va the reworked facies rests on top of glaciolacustrine sand and mud facies.

\section{Diamict, massive with angular or subangular clasts: Dmang}

This lithofacies is interpreted as a gravitational debris flow from a nonglacial source. Two types can be recognized: one where clasts are entirely subangular, angular or very angular, and one where a minority of clasts are subrounded. The former type is present in the North Smolikas Formation (unit SM7; Fig. 8) and is interpreted as colluvium derived from slope processes, which would have been very active following glacier retreat in an oversteepened glacial valley. The latter type is present in the Tsepelovo Formation (unit Vc6; Fig. 5), and is interpreted as a reworked deposit derived from supraglacial and subglacial tills. The clast fabric is relatively weak and the clasts dip in a downvalley direction, unlike the lower units $\mathrm{Vc1}$ and $\mathrm{Vc} 3$, which have strong fabric in the up-valley direction (Figs 1a and 4). The weak clast fabric and clast angularity in this unit suggest that it is a debris flow with fabric related to slope, and gravitational forces, and not former ice movement. Given that this section is through a moraine ridge it is likely that supraglacial and subglacial facies became mixed upon reworking by sediment gravity flow following glacier retreat.

\section{Gravel, massive with subrounded and striated clasts: $G m_{s t}$}

This lithofacies occurs in all sections, except $\mathrm{Vb}$ and $\mathrm{Vc}$ in the Tsepelovo Formation. The subrounded and striated clasts suggest clast abrasion during transport in the subglacial zone. Although sandy gravels form in a range of contemporary depositional settings, including proglacial glaciofluvial settings (Etienne et al. 2003), the massive and poorly sorted nature of these deposits further supports a glacial origin. It is possible that winnowing of fines from original subglacial tills led to the formation of these gravels, especially as they often grade into diamict units below (Figs 6 and 8). Sand lenses within some gravel units (Figs 3 and 6) may reflect the accumulation of fines between clasts voids during the winnowing process. It is possible that the winnowing of fines occurred during meltout, a process observed in a modern glacial setting by Lawson (1979). However, the generally weak clast fabrics $\left(\mathrm{S}_{1}=0.476-0.528\right)$ in this facies contrast with strong fabrics $\left(\mathrm{S}_{1}>0.75\right)$ observed in meltout tills in modern glacial environments (Lawson 1979). This clast-rich gravel facies may have closer parallels to Type I flow deposits identified near the Matanuska glacier in Alaska (Lawson 1979) and represent the subaerial reworking of subglacial tills upon glacier retreat. Alternatively, these types of deposits may have been formed by ablation, whereby subglacial sediment is released at the surface by exposed basal zone ice. This results in a poorly sorted gravel lag deposit with subrounded and striated clasts characteristic of the basal zone and lenses of clay-silt forming in areas of ponding or sand where there is channelized flow (Lawson 1979). Although 


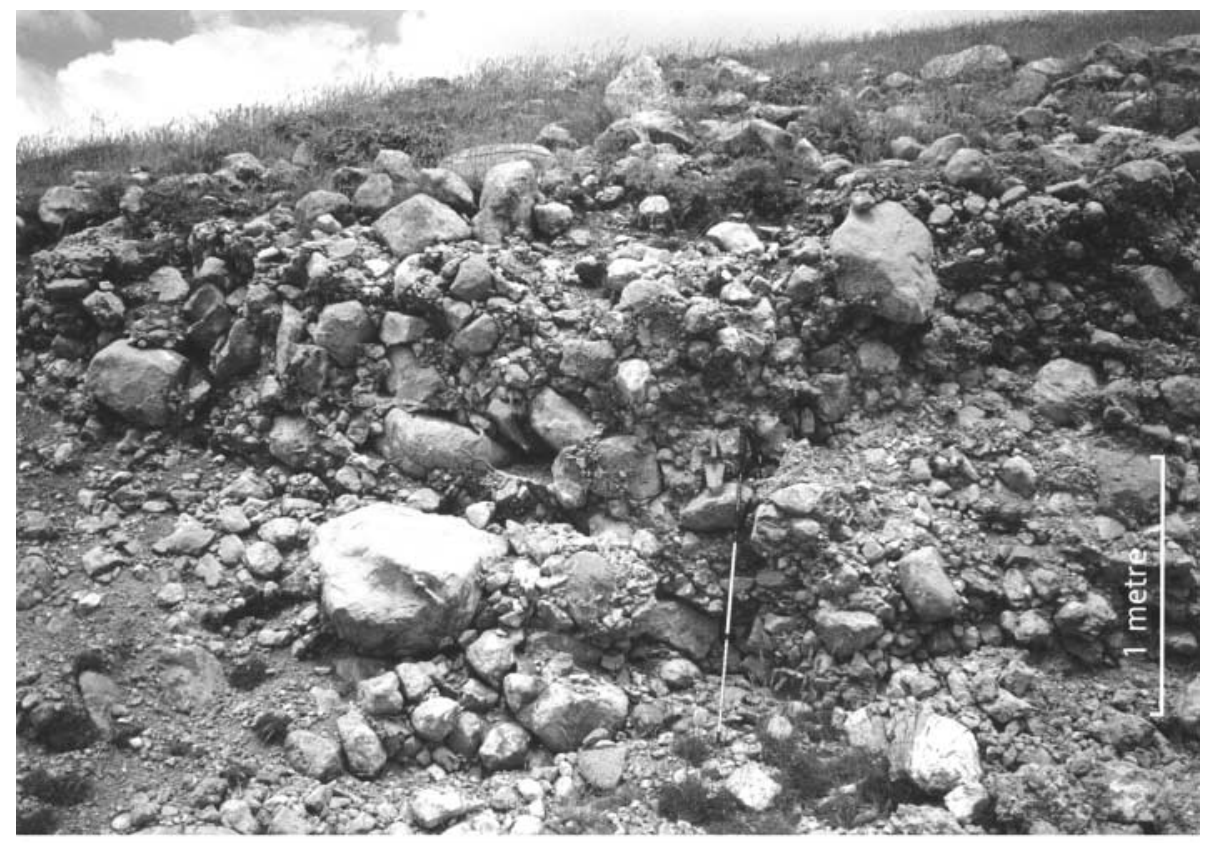

Lithofacies description

KRb: 0 - $2.8 \mathrm{~m}$

Sandy gravel, massive, subrounded and striated clasts (Gmst) Clast density: $60 \%$

Mean size of the ten largest clasts $=519 \mathrm{~mm}$

Clast roundness: R: $4 \%$; SR: $46 \%$; SA: $30 \%$; A: $15 \%$; VA: $5 \%$

Striated clasts: $55 \%$

Matrix grain size: $55 \%$ sand; $29 \%$ silt; $16 \%$ clay;

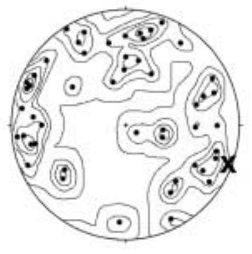

Mean lineations $=109.6^{\circ} 1.0^{\circ}$

$\mathrm{S} 1=0.476$

$\mathrm{S} 2=0.353$

$\mathrm{S} 3=0.171$
Fig. 7. Photograph and sediment description of section $\mathrm{KRb}$ in the Kato Radza Member of the Skamnelli Formation (c. $39^{\circ} 55^{\prime} 58^{\prime \prime} \mathrm{N}, 20^{\circ} 52^{\prime} 09^{\prime \prime} \mathrm{E}, 1773 \mathrm{~m}$ a.s.1.). several modes of formation can explain this facies, they are all associated with meltout or ice retreat and, when exposed, rest on diamicts interpreted as subglacial till $\left(\mathrm{Dm}_{\mathrm{st}}\right)$.

\section{Gravel, bedded: $G b$}

This lithofacies is interpreted as glaciofluvial outwash deposits and is present in units $\mathrm{KRa} 2$ and SM6 of the Skamnelli Formations and North Smolikas, respectively (Figs 6 and 8). The clasts in this facies are subrounded but not striated. Moreover, in unit SM6 the gravels of this facies are dominated by beds of moderately sorted imbricated cobble- to boulder-sized clasts (Fig. 8) suggesting deposition in a high-energy fluvial setting in front of a former valley glacier (see Zieliński \& van Loon 2000). In unit Kra2 (Fig. 6), the gravel is finer and consists of alternating pebble and granule layers, and is interpreted as a more distal proglacial sequence with the alternating clast sizes indicative of varying energy regimes in front of a fluctuating ice margin.

\section{Sands (S) and muds (M)}

This lithofacies is characterized by laminated sands and silty clays with isolated clast inclusions and is present in units Va2$\mathrm{Va} 4$ in the Tsepelovo Formation (Fig. 3). This lithofacies is interpreted as representing deposition in a glaciolacustrine setting, possibly in ponds formed by the meltout of a stagnant ice block associated with the lower till (unit Va1). The isolated clast inclusions within the stratified sands are probably dropstones derived from floating blocks of ice (see Glasser \& Hambrey 2002). The opposite bank of the river to this section exposure is incised into a steep flysch bedrock cliff, which would have been a natural barrier for the former glacier and the setting would have been conducive to ponding.

\section{Discussion}

\section{Multiple Middle Pleistocene glaciations in Greece}

Stacked subglacial tills are exposed in sections in several valleys in the Pindus Mountains and record multiple glacier advances. In places, these are separated by gravel units representing reworked subglacial till and glaciofluvial facies related to meltout and glacier retreat. Interpretations of the landform-sediment associations are discussed below.

On Mount Tymphi, the fullest stratigraphical glacial sequence exposed in section is in section $\mathrm{Vc}$ of the Tsepelovo Formation (Fig. 5). Subglacial till in unit Vc1 was deposited by an extensive valley glacier. Upon retreat, proglacial outwash sands were deposited and are recorded in unit Vc2. Subsequent glacial readvance resulted in the deposition of unit $\mathrm{Vc3}$ and the deformation of units $\mathrm{Vc} 1$ and $\mathrm{Vc} 2$, forming thrust faults, and the partial erosion of the latter unit. Glacier retreat then resulted in the deposition of proglacial outwash sands and unit Vc4. A third glacial phase resulted in the deposition of unit $\mathrm{Vc5}$, the partial erosion of unit $\mathrm{Vc} 3$ and the deformation of the underlying 


\section{$307 \mathbf{\Lambda}$ \\ Lithofacies description
SM7: $27.0->30.0 \mathrm{~m}$
Clast-rich sandy diamicton, massive, angular clasts (Dmang) \\ Clast-rich sandy diamicton, massive, ang
Clast density: 20\%
Clast roundness: SA: 40\%; A: 50\%; VA: 10\%
Striated clasts: 0\%}

$28-$ Matrix composition: $51 \%$ sand; $34 \%$ silt; $15 \%$ clay

SM6: $25.0-27.0 \mathrm{~m}$

Sandy moderately-sorted gravel, bedded (Gb) and imbricated

Clast density: $80 \%$

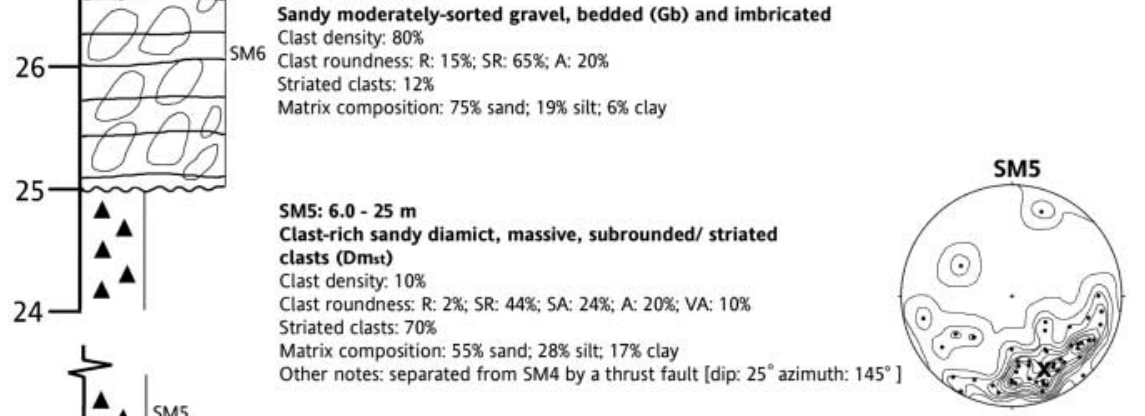

SM4: $5.1-6.0 \mathrm{~m}$

Sandy poorly-sorted gravel, massive, subrounded and $\quad$ X Mean lineation vector $=155.7^{\circ} 28.9^{\circ}$ striated clasts (Gmst)

Clast density. $70 \%$

$\mathrm{S2}=0.222$

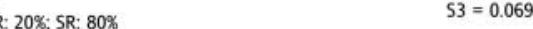

Striated clasts: $80 \%$

Matrix composition: $60 \%$ sand; $28 \%$ silt; $12 \%$ clay

SM3: 3.9 - $5.1 \mathrm{~m}$

Clast-rich sandy diamict, massive, subrounded/ striated clasts (Dmst)

Clasts (Dmst)

Clast roundness: WR: $8 \%$; R: $12 \%$; SR: $36 \%$; SA: 34\%; A: $8 \%$ : VA: $2 \%$

Striated clasts: $88 \%$

Matrix composition: $57 \%$ sand; $29 \%$ silt: $14 \%$ clay

Other notes: separated from SM2 by a thrust fault [dip: $25^{\circ}$ azimuth: $155^{\circ}$ ]

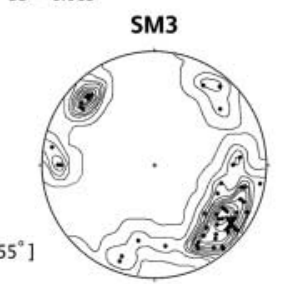

SM2 SM2: 3.0 - $3.9 \mathrm{~m}$

Sandy poorly-sorted gravel, massive, subrounded and $\quad$ X Mean lineation vector $=127.0^{\circ} \quad 14.1^{\circ}$

striated clasts (Gmst)

Clast density: $70 \%$

Clast roundness: R: $10 \%$; SR: $60 \% ;$ SA: $30 \%$

Striated clasts: $80 \%$

Matrix composition: $58 \%$ sand; $26 \%$ silt; $16 \%$ clay

SM1: $0-3.0 \mathrm{~m}$

Clast-rich sandy diamict, massive (Dmst)

Clast density: $10 \%$

Clast roundness: WR: 6\%; R: $18 \%$; SR: 44\%; SA: 22\%; A: 6\%; VA: $4 \%$

Matrix composition: $62 \%$ sand, $22 \%$ silt, $16 \%$ clay.

Striated clasts: $80 \%$

$\mathbf{X}$ Mean lineation vector $=127.0^{\circ} \quad 14.1^{\circ}$
$\mathrm{S} 1=0.742$
$\mathrm{~S} 2=0.173$
$\mathrm{~S} 3=0.086$

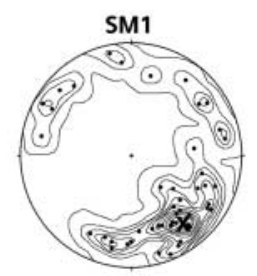

$\mathbf{X}$ Mean lineation vector $=143.1^{\circ} 22.6^{\circ}$ $S 1=0.685$ $\mathrm{S} 2=0.224$ $\mathrm{S} 2=0.224$
$\mathrm{~S} 3=0.091$
Fig. 8. Sediment log of section SM in the North Smolikas Formation on Mount Smolikas (c. $40^{\circ} 08^{\prime} 06^{\prime \prime} \mathrm{N}, 20^{\circ} 54^{\prime} 50^{\prime \prime} \mathrm{E}$, $1080 \mathrm{~m}$ a.s.1.). sediment. The uppermost diamict, unit Vc6, probably formed during glacier retreat and may represent meltout and gravitational reworking of supraglacial debris. Subglacial till is also exposed at section $\mathrm{Vb}$ in the Tsepelovo Formation (Fig. 4) and is likely to be stratigraphically related to one of the subglacial tills exposed in section Vc.

In a neighbouring valley, two stacked subglacial tills are exposed in section KRa (Fig. 6). These tills are separated by a gravel (unit KRa4) interpreted as a sediment flow deposit associated with the reworking of existing subglacial till during meltout. Further intact subglacial tills may be present below a lower gravel unit, KRa1, which is also interpreted as sediment flow deposit. This lowermost gravel unit is separated from the lowest subglacial till unit (KRa3) by a bedded gravel indicative of a proglacial glaciofluvial facies (unit KRa2). No deformation structures are evident in these glaciofluvial deposits, nor in the sediment flow deposits of KRa4, even though both of these units are topped by subglacial tills. This is probably because the gravels of units $\mathrm{KRa} 2$ and $\mathrm{KRa} 4$ would have provided a highly porous and well-drained subglacial bed, resulting in low porewater pressures and high sediment strength (see Boulton 1978). In the Tsepelovo Formation, the absence of clear deformation structures, apart from thrust faults in the stacked subglacial tills of section $\mathrm{Vc}$, may also be a result of low porewater pressures as glaciers advanced over the porous sand beds of $\mathrm{Vc} 2$ and $\mathrm{Vc} 4$ (Fig. 5). 
Elsewhere on Mount Tymphi, sections expose reworked subglacial tills and glaciofluvial deposits, such as in section Va in the Tsepelovo Formation (Fig. 3) and section $\mathrm{KRb}$ in the Skamnelli Formation (Fig. 7). These till units have been dated to $>350 \mathrm{ka}$ BP by applying U-series techniques to secondary calcites within these tills and ascribed to the Skamnellian Stage, which is correlated with MIS 12 (Hughes et al. 2006b).

On Mount Smolikas, three stacked subglacial till facies are exposed and are separated by facies associated with meltout (Fig. 8). This glacial sequence is then topped by a colluvial facies in unit SM7. This sequence is therefore interpreted as representing three separate phases of glacier advance and retreat followed by paraglacial slope adjustment in an overdeepened glacial valley. Similar debris flow deposits to unit SM7 are present in several localities down-valley and, in common with the deposits of SM7, represent the uppermost stratigraphical unit in the area. The village of Aghia Paraskevi is built on similar debris flow deposits (Fig. 1a). The ages of these deposits are unknown, although it is possible that the debris cone may have been initiated under periglacial conditions during the last cold stage, when glaciers were restricted to the highest cirques (Hughes et al. 2006c). However, recent measurements indicate that the debris cone upon which the village of Aghia Paraskevi is built is still active (IGME, Preveza, pers. comm.).

The lower boundary of unit SM3 (Fig. 8) appears to mark the boundary between deposits that have undergone subglacial shear after initial deposition (SM3-SM7) and lower older sediments that appear to be in situ (SM1/2). The lowest units (SM1/2) display evidence for a single cycle of glacier advance and retreat and represent part of the Aghia Paraskevi Member, the deposits of which can be traced c. $0.5 \mathrm{~km}$ further down-valley to an altitude of c. $1000 \mathrm{~m}$ a.s.l. All of the glaciotectonized deposits exposed in units SM3-SM6 form part of the Vadulakkos Member, which is represented by the sediment sequence in conjunction with the surface moraine form (Fig. 9). This upper sequence and the associated surface ridge morphology is interpreted as a composite moraine ridge (see Benn \& Evans 1998, p. 463). There is evidence for oscillation of the glacier snout during the formation of this ridge, with the sedimentary record suggesting at least two glacier advance and retreat cycles (unit SM3/4 and SM5/6). It is likely that these glacial units were initially deposited at the valley floor under an oscillating glacier and then tectonized as a result of glacier thrusting during a later glacier advance.

Based on correlation with the stratigraphical sequence on Mount Tymphi, Hughes (2004) ascribed the deposits of the Aghia Paraskevi Member to the Skamnellian Stage (MIS 12) and those of the Vadulakkos Member to the Vlasian Stage (MIS 6) (Figs 2

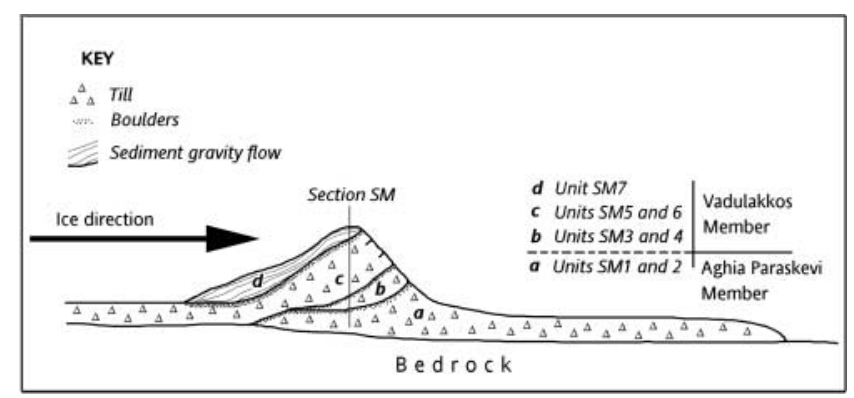

Fig. 9. A schematic diagram showing the down-valley profile of the Vadulakkos moraines and associated units. The moraine is interpreted as a composite moraine formed by ice-thrusting in front of a former valley glacier. and 9). Thus, unlike the glacial sequences recorded in sections on Mount Tymphi, the sequence recorded in the Mount Smolikas section records a combination of glacier advance during separate cold (chronostratigraphical) stages as well as glacier oscillation within the same cold stage. The evidence for only one glacial advance in the deposits of the Skamnellian Stage on Mount Smolikas contrasts with the evidence from Mount Tymphi where three glacier advances are recorded. It is possible that further glacial units are present buried beneath the lowest unit, SM1 (Fig. 8). It is also possible that the Skamnellian Stage Vadulakkos valley glacier did not advance over the locality of section SM more than once, but advanced to positions further up-valley, which would have been overridden by Vlasian Stage ice; thus the geomorphological record would have been obliterated. Nevertheless, the Smolikas section is an important site in the Quaternary record of Greece and it currently represents the only documented locality in the Pindus Mountains where multiple, chronostratigraphically separate, glaciations are exposed in section.

\section{Rapid climate change and glacier response during Middle Pleistocene cold stages in Greece}

Recent analogues from Holocene glaciers in mountain regions clearly demonstrate the potential for major glacier oscillation at decadal and centennial time scales in response to relatively minor climatic fluctuations (e.g. Grove 2004). There is also a large body of evidence for much higher amplitude centennial- to millennial-scale climate changes during the last glacial cycle in ice sheet records from Greenland (Dansgaard et al. 1993) as well as in high-resolution pollen records from the Mediterranean regions of Monticchio in Italy and Ioannina in NW Greece (Allen et al. 1999; Tzedakis et al. 2004). In fact, high-frequency suborbital climate variability similar to that observed for the last glacial cycle appears to have been a pervasive feature over the last $500 \mathrm{ka}$ in the North Atlantic region (McManus et al. 1999). It is therefore likely that Middle Pleistocene glacial cycles in the Pindus Mountains were characterized by rapid and high-amplitude climate change. Indeed, suborbital frequencies have been noted in the relative pollen abundance of forest and open vegetation communities at Tenaghi Philippon in NE Greece for the last $450 \mathrm{ka}$ (Tzedakis et al. 2003). The sedimentological record of multiple phases of glacier advance and retreat within Middle Pleistocene glacial cycles in Greece may have been in response to these rapid climate changes.

\section{Middle Pleistocene surging glaciers in Greece}

The presence of thick sequences of deformed and tectonized till units in all areas may indicate former glacier surging in the Pindus Mountains. Glaciers that advance over existing glacial deposits are prone to surging, as coupling can occur between the glacier and a soft deformable bed, which has been linked with fast glacier flow (Clarke 1994; Alley 1991). Furthermore, the presence of stacked and tilted diamicton units on both Mount Smolikas and Mount Tymphi is best explained by proglacial thrusting, possibly in front of a surging glacier in response to changes in the dynamic mode of a polythermal glacier (see Huddart \& Hambrey 1996; Hambrey et al. 1999). Rapid climate oscillations during Middle Pleistocene cold stages would have been directly reflected in glacier mass balance, which in turn would have impinged on the former glacier thermal regime, compounding glacier instability in response to changing climatic variables, and thus enhancing the susceptibility of these Greek glaciers to surging. 


\section{Multiple glaciations and implications for interpreting the stratigraphical record}

The recognition of multiple glacier advances over a fixed locality within mountain glacial sequences has an important bearing on the stratigraphical classification of the surface landform. Stratigraphical subdivision based on morphological criteria has the potential to allow recognition of glacier advances through the presence of multiple moraine suites within a cirque-valley system. However, morphological criteria alone cannot separate the glacier advance that formed the landform from the sediment sequence that it comprises. For example, the sediment-landform assemblages exposed at sections $\mathrm{Vc}, \mathrm{KRa}$ and SM (Figs 5, 6 and 8) are not only the product of the glacier advance recorded by the surface form, but are also the product of earlier glacial advances. In the case of the Tymphi sections, Vc and KRa (Figs 5 and 6), these glacial advances appear to have occurred within a single glacial cycle. However, in the Smolikas sequence (Fig. 8), these glacial advances appear to have taken place within both single and multiple glacial cycles. In areas where old tills from different glacial cycles are deformed and tectonized by later glacial advances, the question arises as to whether each separate glacial unit should remain associated with the glacial episode that produced it, or should be considered coeval with the surface landform. The answer probably lies in the degree of deformation, and it can be argued that glacial units that lose many of their original characteristics should be considered equivalent in age to the forces that deformed them. In the case of a tectonized moraine ridge, this is the age of the landform itself. However, for a vertical sediment sequence, the boundary between glaciotectonite and undeformed original glacial deposits could represent the lithostratigraphical division between different glacial units. This boundary would be defined as the base of the exodiamict glaciotectonite in the scheme of Banham (1977), the base of the overturned zone in the scheme of Hart \& Boulton (1991) or merely at the base of glaciotectonite as defined by Benn \& Evans (1996). For example, in the case of the Smolikas section, this is defined by the base of unit SM3 (Fig. 8). However, such a boundary will not always be clear and gradations between parent till and glaciotectonite are likely to vary laterally in response to varying strengths of a nonhomogeneous parent layer.

The issue of inheritance in glaciated landscapes is not only important in interpreting the sediment stratigraphical record but can also be significant in interpreting surface landforms. For example, Möller (2006) demonstrated that Rogen moraines in Sweden represent glacial reshaping of pre-existing transverse moraine ridges. Although Rogen moraines usually characterize lowland glacial sequences, evidence of similar reshaping of preexisting glacial deposits is widely recorded in glaciated upland areas (Benn \& Evans 1996) and is clearly demonstrated in the results presented from the Pindus Mountains, Greece. In fact, glaciers may have formed during glacial intervals between the Skamnellian and Vlasian Stages, such as during the early Saalian and MIS 10 or 8 , only to be overridden by the Vlasian glaciers and incorporated into the deposits assigned to this stage. Thus, glacial sequences clearly pose challenges for stratigraphical subdivision, and, if such sequences are to contribute to integrated terrestrial stratigraphical frameworks, then issues such as sediment and landform inheritance must be addressed. This is particularly the case for locally glaciated mountain regions, such as in the Pindus Mountains, where temporally extensive yet spatially limited glacial sequences represent a key component of the Quaternary record.

\section{Conclusions}

(1) Stacked diamicts separated by gravels record multiple phases of former glacier advance and retreat in the Pindus Mountains, NW Greece.

(2) On Mount Tymphi, there is evidence of at least three episodes of glacier advance and retreat during the Skamnellian Stage of the Middle Pleistocene, which is correlated with the Elsterian Stage of northern Europe and MIS 12.

(3) On Mount Smolikas, an exposed section records at least one phase of glacier advance and retreat during the Skamnellian Stage and two phases of advance and retreat during the later Vlasian Stage, which is correlated with the late Saalian Stage of northern Europe and MIS 6.

(4) The evidence of thick accumulations of multiple stacked till units separated by thrust faults may record glacier surging beneath a polythermal glacier in response to changing conditions caused by rapid climatic changes during Middle Pleistocene cold stages.

(5) In locally glaciated mountain regions, glacier advance over pre-existing glacial deposits can result in complex sedimentlandform associations and has important implications for stratigraphical subdivision. The tectonic and deformational history of glacial sequences in locally glaciated mountain regions requires careful consideration if these spatially restricted yet potentially temporally extensive records are to be better understood.

(6) In the Pindus Mountains of Greece, complex glacial sedimentological sequences provide evidence not only for glacial advances during multiple Middle Pleistocene cold stages, but also for climate instability within single cold stages. Evidence for the latter is important in understanding variations in former glacier mass balance and is essential for unravelling complex glacier-climate histories based on the glacial record.

P.D.H. was funded by a University of Cambridge Domestic Research PhD Studentship and a University of Manchester Faculty of Humanities PostDoctoral Fellowship. This research was also made possible by fieldwork grants from Darwin College, University of Cambridge; the Cambridge European Trust; the Quaternary Research Association; the British Geomorphological Research Group; Worts Travelling Scholarship, University of Cambridge; Cambridge Philosophical Society; and the Department of Geography, University of Cambridge. The most recent U-series dating programme was undertaken at the Uranium Series Facility in the Department of Earth Sciences, Open University, Milton Keynes, supported by the Natural Environment Research Council (Reference Number IP/754/0302). All field work was undertaken with permission and support of the Institute of Geological and Mineral Exploration (IGME) of Greece. The authors thank M. Hambrey, M. Krabbendam and an anonymous reviewer for very helpful comments, which helped improve an earlier draft of this paper.

\section{References}

Allen, J.R.M., Brandt, U. \& Brauer, A. et AL. 1999. Rapid environmental changes in southern Europe during the last glacial period. Nature, 400, $740-743$.

Alley, R.B. 1991. Deforming bed origin for southern Laurentide ice sheets? Journal of Glaciology, 37, 67-76.

Banham, P.H. 1977. Glacitectonites in till stratigraphy. Boreas, 6, 101-105.

BENN, D.I. 1995. Fabric signature of till deformation, Breidamerkurjökull, Iceland. Sedimentology, 42, 735-747.

BenN, D.I. \& Evans, D.J.A. 1996. The interpretation and classification of subglacially deformed materials. Quaternary Science Reviews, 15, 23-52.

Benn, D.I. \& Evans, D.J.A. 1998. Glaciers and Glaciation. Arnold, London.

Boenzi, F., Palmentola, G., Sanso, P. \& Tromba, F. 1992. Le tracce glaciali del massiccio dello Smolikas catena del Pindo-Grecia. Rivista Geografica Italiana, 99, 379-393.

Boulton, G.S. 1978. Boulder shapes and grain-size distributions of debris as indicators of transport paths through a glacier and till genesis. Sedimentology, 25, 773-799. 
Boulton, G.S., Dent, D.L. \& Morris, E.M. 1974. Subglacial shear formation and crushing in lodgement tills from south-east Iceland. Geografiska Annaler, 56A, 135-145.

Calvet, M. 2004. The Quaternary glaciation of the Pyrenees. In: Ehlers, J. \& GibBard, P.L. (eds) Quaternary Glaciations-Extent and Chronology. Part I: Europe. Elsevier, Amsterdam, 119-128.

Clarke, P.U. 1994. Unstable behaviour of the Laurentide Ice Sheet over deforming sediment and its implications for climate change. Quaternary Research, 41, $19-25$.

Dansgaard, W., Johnsen, S.J. \& Clausem, H.B. et aL. 1993. Evidence for general instability of past climate from a 250 -year ice-core record. Nature, 364, 218-220.

Etienne, J.L., Glasser, N.F. \& Hambrey, M.J. 2003. Proglacial sedimentlandform associations of a polythermal glacier: Storglaciären, Northern Sweden. Geografiska Annaler, 85A, 149-164.

Evans, D.J.A. \& Benn, D.I. (eds) 2004. A Practical Guide to the Study of Glacial Sediments. Arnold, London.

FEDERICI, P.R. 1980. On the Riss glaciation of the Apennines. Zeitschrift für Geomorphologie, 24, 111-116.

Fernadez Mosquera, D., Marti, K., Vidal Romani, J.R. \& Weigel, A. 2000. Late Pleistocene deglaciation chronology in the NW of the Iberian Peninsula using cosmic-ray produced ${ }^{21} \mathrm{Ne}$ in quartz. Nuclear Instruments and Methods in Physics Research, B172, 832-837.

Glasser, N.F. \& Hambrey, M.J. 2001. Styles of sedimentation beneath Svalbard valley glaciers under changing dynamic and thermal regimes. Journal of the Geological Society, London, 158, 697-707.

Glasser, N.F. \& Hambrey, M.J. 2002. Sedimentary facies and landform genesis at a temperate outlet glacier: Soler glacier, North Patagonian Icefield. Sedimentology, 49, 43-64.

Grove, J. 2004. Little Ice Ages: Ancient and Modern, Volumes I and II. Routledge, London.

Hambrey, M.J. 1994. Glacial Environments. UCL Press, London.

Hambrey, M.J., Huddart, D., Bennett, M.R. \& Glasser, N.F. 1999. Debris entrainment and transfer in polythermal glaciers. Journal of the Geological Society, London, 154, 623-632.

Hart, J. 1994. Till fabric associated with deformable beds. Earth Surface Processes and Landforms, 19, 15-32.

Hart, J.K. \& Boulton, G.S. 1991. The inter-relation of glacio-tectonic and glaciodepositional processes within the glacial environment. Quaternary Science Reviews, 10, 335-350.

Huddart, D. \& Hambrey, M.J. 1996. Sedimentary and tectonic development of a high-arctic, thrust-moraine complex: Comfortlessbreen, Svalbard. Boreas, 25, 227-243.

Hughes, P.D. 2004. Quaternary glaciation in the Pindus Mountains, Northwest Greece. $\mathrm{PhD}$ thesis, University of Cambridge.

Hughes, P.D., Gibbard, P.L. \& Woodward, J.C. 2003. Relict rock glaciers as indicators of Mediterranean palaeoclimate during the Last Glacial Maximum Late Würmian of northwest Greece. Journal of Quaternary Science, 18, $431-440$.

Hughes, P.D., Gibbard, P.L. \& Woodward, J.C. 2005. A formal stratigraphical approach for Quaternary glacial records in mountain regions. Episodes, 28, 85-92.

Hughes, P.D., Woodward, J.C. \& Gibbard, P.L. 2006a. Quaternary glacial history of the Mediterranean mountains. Progress in Physical Geography, 30, in press.
Hughes, P.D., Woodward, J.C., Gibbard, P.L., Macklin, M.G., Gilmour, M.A. \& SMITH, G.R. 2006b. The glacial history of the Pindus Mountains, Greece. Journal of Geology, 114, in press.

Hughes, P.D., Woodward, J.C. \& Gibbard, P.L. 2006c. The last glaciers of Greece. Zeitschrift für Geomorphologie, 50, 37-61.

IGME, 1970. 1:50000 geological map of Greece. Tsepelovon Sheet. Institute of Geological and Mineral Exploration: Athens.

IGME, 1987. 1:50000 geological map of Greece. Konitsa Sheet. Institute of Geological and Mineral Exploration: Athens.

Jones, A.P., Tucker, M.E. \& HART, J.K. (EDS) 1999. The Description and Analysis of Quaternary Stratigraphic Field Sections. Technical Guide. Quaternary Research Association, London, 7.

Kotarba, A., Hercman, H. \& Dramis, F. 2001. On the age of Campo Imperatore glaciations, Gran Sasso Massif, Central Italy. Geografia Fisica e Dinamica Quaternaria, 24, 65-69.

Lawson, D.E. 1979. Sedimentological analysis of the western terminus region of the Matanuska Glacier, Alaska. US Army Cold Regions Research and Engineering Laboratory, Hanover, NH, Research Report, 79/9.

Lewin, J., Macklin, M.G. \& Woodward, J.C. 1991. Late Quaternary fluvial sedimentation in the Voidomatis Basin, Epirus, northwest Greece. Quaternary Research, 35, 103-115.

McManus, J.F., Oppo, D.W. \& Cullen, J.L. 1999. A 0.5 million-year record of millennial-scale climate variability in the North Atlantic. Science, 283, 971975.

MöLler, P. 2006. Rogen moraine: an example of glacial reshaping of pre-existing landforms. Quaternary Science Reviews, 25, 362-389.

MoncriefF, A.C.M. 1989. Classification of poorly sorted sedimentary rocks. Sedimentary Geology, 65, 191-194.

Palmentola, G., Boenzi, F., Mastronuzzi, G. \& Tromba, F. 1990. Osservazioni sulle tracce glaciali del M. Timfi, catena del Pindo Grecia. Geografia Fisica e Dinamica Quaternaria, 13, 165-170.

Smith, G.W., Nance, R.D. \& Genes, A.N. 1997. Quaternary glacial history of Mount Olympus. Geological Society of America Bulletin, 109, 809-824.

Tzedakis, P.C., McManus, J.F., Hooghiemstra, H., Oppo, D.W. \& Wijmstra, T.A. 2003. Comparison of changes in vegetation in northeast Greece with records of climate variability on orbital and suborbital frequencies over the last 450,000 years. Earth and Planetary Science Letters, 212, 197-212.

Tzedakis, P.C., Frogley, M.R., Lawson, i.T., Preece, R.C., Cacho, I. \& de Abreu, L. 2004. Ecological thresholds and patterns of millennial-scale climate variability: the response of vegetation in Greece during the last glacial period. Geology, 32, 109-112.

Woodward, J.C., Lewin, J. \& Macklin, M.G. 1992. Alluvial sediment sources in a glaciated catchment: the Voidomatis basin, northwest Greece. Earth Surface Processes and Landforms, 16, 205-216.

Woodward, J.C., Lewin, J. \& Macklin, M.G. 1995. Glaciation, river behaviour and Palaeolithic settlement in upland northwest Greece. In: WoODWARD, J.C., MaCKLIN, M.G. \& Lewin, J. (eds) Mediterranean Quaternary River Environments. Balkema, Rotterdam.

Woodward, J.C., Macklin, M.G. \& SMith, G.R. 2004. Pleistocene glaciation in the mountains of Greece. In: Ehlers, J. \& Gibbard, P.L. (eds) Quaternary Glaciations-Extent and Chronology. Part I: Europe. Elsevier, Amsterdam, $155-173$.

ZIELIŃSKI, T. \& VAN LoON, A.J. 2000. Subaerial terminoglacial fans III: overview of sedimentary characteristics and depositional model. Geologie en Mijnbouw, 79, 93-107. 